\title{
Why Do Family-controlled Firms Donate to Charity? The Role of Intrafamily Succession Intention, Social Status, and Religiosity
}

\author{
Weiwen Li, ${ }^{1}$ Kevin Yuk-fai Au, ${ }^{2} \mathrm{Ai} \mathrm{He},{ }^{3}$ and Lihong Song ${ }^{4}$ \\ ${ }^{1}$ Sun Yat-sen University, China, ${ }^{2}$ The Chinese University of Hong Kong, Hong Kong, ${ }^{3}$ South China \\ University of Technology, China, and ${ }^{4}$ Shantou University, China
}

\begin{abstract}
Drawing on expectancy theory and the socioemotional wealth (SEW) perspective, we propose that family owners with intrafamily succession intention are more motivated to accumulate or preserve SEW. As corporate philanthropy is a critical way for family-controlled firms to accumulate or maintain SEW, family owners with intrafamily succession intention are more likely to engage in corporate philanthropic activities. Data on a nationally representative sample of family-controlled firms in China support our prediction. We also find that the relationship between intrafamily succession intention and corporate philanthropy is moderated by family owners' social status and religiosity. The findings contribute to our understanding about family businesses, in general, and those in China, in particular, as well as the SEW perspective.
\end{abstract}

KEYWORDS family-controlled firms, intrafamily succession intention, religiosity, social status, socioemotional wealth

\section{INTRODUGTION}

Family-controlled firms are those in which 'a family owner exercises much influence over the firm's affairs' (Gomez-Mejia, Cruz, Berrone, \& De Castro, 2011: 658). This form of business is ubiquitous and numerically dominant throughout the world (Au, Craig, \& Ramachandran, 2011; Gomez-Mejia, Larraza-Kintana, \& Makri, 2003; La Porta, Lopez-de-Silanes, \& Shleifer, 1999; Lu, Au, Peng, \& Xu, 2013). One of the key differences between family-controlled and nonfamily-controlled firms is that the former are more inclined to sacrifice economic gains to accumulate or maintain the noneconomic utility - or, formally, socioemotional wealth (SEW) - which a family would derive from its association with the firm (Gómez-Mejía, Haynes, Núñez-Nickel, Jacobson, \& Moyano-Fuentes, 2007). Studies have shown that SEW consideration is the primary driver of many behaviors of family-controlled firms, including corporate diversification, environmental performance, initial public 
offering underpricing, and investment in research and development (Berrone, Cruz, Gomez-Mejia, \& Larraza-Kintana, 2010; Chrisman \& Patel, 2012; Gomez-Mejia et al, 2007; Gomez-Mejia, Makri, \& Larraza-Kintana, 2010; Leitterstorf \& Rau, 2014).

Such studies are valuable for showing the uniqueness of family-controlled firms, but they imply that family-controlled firms 'are homogeneous in their emphasis on SEW considerations' (Berrone, Cruz, \& Gomez-Mejia, 2012: 270). As not all family-controlled firms emphasize SEW to the same extent, the studies do not give a systematic account of the variation among family-controlled firms (Chrisman \& Patel, 2012; Chua, Chrisman, \& Sharma, 1999; Naldi, Cennamo, Corbetta, \& Gomez-Mejia, 2013). Even though recent studies have suggested that family-controlled firms vary greatly regarding their behaviors driven by SEW considerations (Chrisman \& Patel, 2012; Chua, Chrisman, Steier, \& Rau, 2012), few studies have assessed or accounted for this heterogeneity (Chrisman \& Patel, 2012).

Another deficiency in studies applying the SEW perspective is that they used family ownership as a proxy for the existence of SEW, thus ignoring the possibility that family owners might have different levels of motivation to accumulate or maintain SEW. Failing to account for family owners' varying motivations in our progress toward a theory of SEW is unfortunate, because according to motivation theories, individuals vary greatly regarding their motivations to behave in a particular way (Latham \& Pinder, 2005). To the extent that family owners are the key decision makers in family-controlled firms, an examination of their motivations would contribute to a better understanding of the behaviors that are driven by SEW considerations in family-controlled firms.

This study is an attempt to fill these research gaps with a focus on the corporate philanthropy of family-controlled firms in China (Cui, Liang, \& Lu, 2015). Uniting the SEW perspective with expectancy theory, a classic motivation theory on individual decision making (Vroom, 1964), we propose that family owners' motivation to engage in corporate philanthropic activities is determined by the perceived probability that corporate philanthropy will lead to a positive outcome (i.e., expectancy) and by the attractiveness of that positive outcome (i.e., valence). Following this logic, we propose that corporate philanthropy is likely to contribute to a positive reward, namely, SEW, and family owners with intrafamily succession intention tend to place a higher value on such a reward. As a result, these family owners are motivated to make more charitable contributions. Moreover, family owners with high social status will raise their expectation that corporate philanthropy is closely related with family SEW (Yiu, Wan, Ng, Chen, \& Su, 2014). Hence, family owners' social status will strengthen the relationship between intrafamily succession intention and corporate philanthropy. In addition, we posit that family owners with religiosity are likely to be intrinsically motivated and value corporate philanthropy itself rather than the extrinsic reward derived from philanthropic activities (i.e., SEW). As a result, intrafamily succession intention 
will be a weaker motivating factor influencing corporate philanthropy when family owners are already strongly motived by religiosity.

This study makes three main contributions to the literature. First, building on insight from expectancy theory, we propose that family owners' motivations are key determinants of heterogeneity among family-controlled firms. In particular, we identify that the behaviors of family-controlled firms can be driven by both extrinsic and intrinsic motivations. These findings help to build a stronger theoretical foundation for understanding the behavior of family-controlled firms.

Second, our study contributes to the research on SEW by taking into account both family owners' ability and motivations to accumulate and maintain SEW. Prior studies on SEW focused mainly on family involvement as a key determinant of behavior related to SEW considerations, as that factor provides family owners the ability to pursue SEW. The results of this study demonstrate that without understanding family owners' motivations, one may fail to fully grasp the behaviors of family-controlled firms.

Third, this study takes into account the institutional context in China. The recent institutional developments in China have greatly enhanced the social status of family owners and have resulted in increasing numbers of family owners publicly declaring their religious affiliations. These developments provide a unique context for testing the interplay of ability and motivation for family firms' particularistic behavior.

\section{INSTITUTIONAL BAGKGROUND}

In the past few decades, the institutional background in China, particularly that related to the growth of privately owned firms, has changed dramatically. Table 1 presents the main institutional changes during this period. As all family-controlled firms are privately owned firms, a discussion of these institutional changes will help us understand the behaviors of family-controlled firms in China.

\section{The Evolving Status of Private Business Owners in China}

In traditional Chinese society, which was greatly influenced by Confucianism, private business owners were of relatively low social status. In Confucian teachings, society is divided into the scholar (shi), farmer (nong), artisan (gong), and merchant (shang) classes. Accordingly, private business owners and merchants have traditionally been placed toward the bottom of society in Chinese culture, viewed as not producing anything and only profiting from others' creations (Mencius, 1895).

The social status of private business owners did not improve after the Communist Party of China (CPG) won the civil war and founded the People's Republic of China (PRC) in 1949. Between 1952 and 1977, the overall political environment was antagonistic toward the private sector, which was regarded as the 'tail of capitalism' and completely banned in China. Although private business was revived after the 
Table 1. Institutional environment in China

\begin{tabular}{|c|c|c|c|c|}
\hline Period & $\begin{array}{l}\text { Key laws or } \\
\text { regulations }\end{array}$ & Social status & Political treatment & Religious environment \\
\hline $\begin{array}{r}\text { Before } \\
1949\end{array}$ & $\begin{array}{l}\text { Han Law } \\
\qquad(221-207 \\
\text { BC) }\end{array}$ & $\begin{array}{l}\text { Society was divided } \\
\text { into the classes of } \\
\text { scholar, farmer, } \\
\text { artisan, and } \\
\text { merchant, and } \\
\text { private business } \\
\text { owners were at } \\
\text { the bottom of } \\
\text { society. }\end{array}$ & $\begin{array}{l}\text { Private business } \\
\text { owners were } \\
\text { forbidden to buy } \\
\text { land or hold } \\
\text { office. }\end{array}$ & $\begin{array}{l}\text { Religions, } \\
\text { including foreign } \\
\text { ones, were } \\
\text { tolerated, as long } \\
\text { as they did not } \\
\text { threaten the } \\
\text { ruling state with } \\
\text { disaffection and } \\
\text { rebellion. }\end{array}$ \\
\hline 1949-1978 & $\begin{array}{l}\text { Interim } \\
\text { regulations } \\
\text { on public- } \\
\text { private joint } \\
\text { management } \\
(1956)\end{array}$ & $\begin{array}{l}\text { Private enterprises } \\
\text { were completely } \\
\text { banned in } \\
\text { China. }\end{array}$ & $\begin{array}{l}\text { Private business } \\
\text { owners were } \\
\text { treated as an } \\
\text { exploiting class. }\end{array}$ & $\begin{array}{l}\text { All religious sites } \\
\text { were closed; only } \\
\text { a few believers } \\
\text { remained. }\end{array}$ \\
\hline $1980 \mathrm{~s}$ & $\begin{array}{l}\text { Some policy } \\
\text { stipulations } \\
\text { of the state } \\
\text { council on } \\
\text { the urban } \\
\text { nonagricul- } \\
\text { tural } \\
\text { individual } \\
\text { economy } \\
(1981)\end{array}$ & $\begin{array}{l}\text { Private sector was } \\
\text { regarded as a } \\
\text { marginal sector } \\
\text { to be tolerated } \\
\text { temporarily and } \\
\text { tightly controlled } \\
\text { by the state. }\end{array}$ & $\begin{array}{l}\text { Private business } \\
\text { owners were } \\
\text { carefully } \\
\text { controlled and } \\
\text { denied entrance } \\
\text { into the political } \\
\text { establishment. }\end{array}$ & $\begin{array}{l}\text { Religious activities } \\
\text { were tolerated, } \\
\text { and a limited } \\
\text { number of } \\
\text { religious sites } \\
\text { were allowed to } \\
\text { reopen for } \\
\text { religious services. }\end{array}$ \\
\hline $1990 \mathrm{~s}$ & $\begin{array}{l}\text { Decision of the } \\
\text { Central } \\
\text { Committee } \\
\text { on some } \\
\text { issues } \\
\text { concerning } \\
\text { the establish- } \\
\text { ment of a } \\
\text { socialist } \\
\text { market } \\
\text { economic } \\
\text { structure } \\
\text { (1993) }\end{array}$ & $\begin{array}{l}\text { Ownership } \\
\text { discrimination } \\
\text { was abandoned } \\
\text { and the private } \\
\text { sector was } \\
\text { accorded equal } \\
\text { status with other } \\
\text { sectors. }\end{array}$ & $\begin{array}{l}\text { Ideological } \\
\text { restrictions were } \\
\text { loosened and } \\
\text { some private } \\
\text { business owners } \\
\text { became } \\
\text { members of the } \\
\text { PC and CPPCC. }\end{array}$ & $\begin{array}{l}\text { The State Council } \\
\text { published two } \\
\text { ordinances that } \\
\text { required all } \\
\text { religious groups } \\
\text { to register with } \\
\text { the government } \\
\text { and prohibited } \\
\text { foreigners from } \\
\text { proselytizing in } \\
\text { China. }\end{array}$ \\
\hline $2000 \mathrm{~s}$ & $\begin{array}{l}\text { Amendment to } \\
\text { the } \\
\text { Constitution } \\
\text { of the } \\
\text { People's } \\
\text { Republic of } \\
\text { China (2004) }\end{array}$ & $\begin{array}{l}\text { The private sector } \\
\text { was regarded as } \\
\text { a significant } \\
\text { contributor to } \\
\text { China's } \\
\text { economic } \\
\text { development. }\end{array}$ & $\begin{array}{l}\text { Private business } \\
\text { owners were } \\
\text { formally allowed } \\
\text { to apply for } \\
\text { membership in } \\
\text { the Communist } \\
\text { Party of China. }\end{array}$ & $\begin{array}{l}\text { Official policies } \\
\text { toward religions } \\
\text { were further } \\
\text { softened, but the } \\
\text { State still } \\
\text { controls the } \\
\text { growth and } \\
\text { scope of religious } \\
\text { activities. }\end{array}$ \\
\hline
\end{tabular}


11 th Central Committee's 3rd Plenum, private business owners were still treated with suspicion and even considered despicable in the 1980s. The private ownership of firms was considered to be an inferior form of business ownership for ideological reasons.

This political and social discrimination against private business owners has gradually decreased since the early 1990s. Ideological opposition to private enterprise has subsided and the private sector has been accorded equal status with other sectors. One of the most significant changes in the political status of private business owners occurred during the CPC's 16th Congress in 2002 when the membership charter was revised and private business owners were formally allowed to apply for CPC membership. This loosening of the ideological and political constraints in China raised the social status of private business owners to such an extent that an increasing number of government employees have quit their jobs to start their own businesses.

\section{State Policies toward Religion}

Despite the relaxed ideological and political constraints, the Chinese government still maintains tight control over the growth and scope of religious activities. Before the founding of the PRC in 1949, the state maintained loose control over religious groups. Almost all religions, including foreign ones, were tolerated, as long as they did not threaten the stability of the state. Some emperors even had religious affiliations. For example, Emperor Jiajing in the Ming Dynasty was a devoted follower of Taoism, and Emperor Shunzhi in the Qing Dynasty became a devout follower of Buddhism in 1657.

When the PRC was founded in 1949, religious activities were suppressed by the CPC, which is officially atheistic. During the Cultural Revolution from 1966 to 1976, many religious sites and artifacts in China were damaged, and religious scriptures were burned. Monks and priests were 'wiped away like dust' through imprisonment and re-education in labor camps.

In the post-1979 era, the pragmatic CPC began to loosen control over various social activities, including religion. In the 1980s, suppression was replaced with tolerance, and a limited number of places for worship, including Protestant and Catholic churches, Buddhist and Taoist temples, and Islamic mosques, were allowed to reopen for religious services.

\section{THEORETICAL BACKGROUND AND HYPOTHESES}

\section{SEW Perspective and the Behaviors of Family-controlled Firms}

According to the SEW perspective, family-controlled firms place a higher value on SEW than do nonfamily-controlled firms (Berrone et al., 2012). As a result, they are likely to be very interested in keeping control over their firms, perpetuating the 
family dynasty, and sustaining the family image and reputation. To accumulate or maintain SEW, family owners are willing to engage in behavior that is not driven by economic logic (Berrone et al., 2010; Gomez-Mejia et al., 2007).

Recent studies on family-controlled firms have relied frequently on the SEW perspective to predict the differences in the strategic choices and practices of familycontrolled and nonfamily-controlled firms (Chrisman \& Patel, 2012; Gomez-Mejia et al., 2011). Focusing mainly on differences in firm behavior between familycontrolled and nonfamily-controlled firms (Patel \& Chrisman, 2014), they have assumed that family-controlled firms 'are homogeneous in their emphasis on SEW considerations' (Berrone et al., 2012: 270). However, the family business literature suggests that in some situations, the variations among family-controlled firms can be as large as, if not larger than, the differences between family-controlled and nonfamily-controlled firms (Chrisman \& Patel, 2012; Chua et al., 2012). Big differences of emphasis in SEW may actually exist among family-controlled firms.

In addition, most of these studies have used family ownership as a proxy for the existence of SEW (Berrone et al., 2012; Chrisman \& Patel, 2012). Family ownership can be a valid approximation of SEW when using archival data (Naldi et al., 2013). However, studies have recently suggested that not all family owners have the same level of motivation to accumulate and maintain SEW (Chrisman \& Patel, 2012). Hence, directly studying the motivations of family owners might better capture the decision-making process related to SEW considerations (Kellermanns, Eddleston, \& Zellweger, 2012; Naldi et al., 2013).

\section{Drivers of Charitable Donations}

Expectancy theory explains the process individuals use to make decisions regarding behavioral alternatives (Vroom, 1964). Organizational psychology literature includes a number of different motivational theories; we selected expectancy theory to derive our hypotheses for several reasons. First, this theory has been used for understanding prosocial behavior and organization citizenship behavior (Grant \& Berg, 2011; Grant \& Mayer, 2009); thus, it is useful for theorizing how family owners' motivations may affect their engagement in corporate philanthropic activities. Second, expectancy theory provides a comprehensive framework for assessing individual behaviors (Fudge \& Schlacter, 1999). It has the advantage of identifying and systematically relating the various attributes of family owners to their likelihood of making charitable donations. Third, this theory has been subjected to rigorous empirical testing and is one of the most commonly used theories of motivation in organizational settings (Chiang \& Jang, 2008).

According to expectancy theory, there are two basic prerequisites underlying an individual's motivation to engage in a behavior: expectancy and valence (Chen \& Miller, 1994; Fudge \& Schlacter, 1999; Vroom, 1964). Expectancy is the perceived probability that effort in an activity will lead to desired outcomes (Vroom, 1964). Valence refers to the subjective reward value or the attractiveness 
of the behavioral outcome (Chen \& Miller, 1994; Chiang \& Jang, 2008). Because expectancy and valence are both prerequisites of a behavior, these two factors combine multiplicatively to determine an individual's motivation to behave. In general, empirical studies on individual motivation in the workplace have provided strong support for this theory (Fudge \& Schlacter, 1999).

In this study, we use expectancy theory and the SEW perspective to argue that family owners are heterogeneous in their motivations for engaging in corporate philanthropic activities. In particular, family owners with intrafamily succession might have stronger motivations to make charitable contributions because making charitable contributions is highly likely to contribute to a positive outcome (i.e., family image and reputation), and these family owners place a high value on such outcome. In the language of expectancy theory, since both the effort-outcome expectancy and outcome valence are high, these family owners are motivated to make charitable donations.

Moreover, not all family owners have the same effort-outcome expectancy. Only those who are confident that corporate donations have a high likelihood of leading to SEW will engage in such philanthropic activities (Tsiros, Mittal, \& Ross, 2004; Vroom, 1964). Following this logic, as there would be more social monitoring and scrutiny from company stakeholders, family owners who are of high social status, we propose, would tend to believe that corporate philanthropy is closely related to family image and reputation (Zellweger, Nason, Nordqvist, \& Brush, 2013). For this reason, having a higher social status is likely to strengthen the relationship between intrafamily succession intention and corporate philanthropy.

The foregoing arguments are based on the assumption that family owners are selfinterested individuals who desire to accumulate and maintain SEW. In other words, family owners are motivated to engage in corporate philanthropic activities mainly because of the extrinsic value derived from such activities (Cennamo, Berrone, Cruz, \& Gomez-Mejia, 2012). However, family owners can also be interested in charity in and of itself, and they may derive intrinsic satisfaction by engaging in corporate philanthropic activities. In particular, we propose that those with religious faith tend to value corporate philanthropy intrinsically; thus, they have a lower valence for SEW that is generated from corporate philanthropy. In this sense, religiosity will weaken the relationship between intrafamily succession intention and corporate philanthropy.

Based on these arguments, this research focuses on three factors that are expected to influence family owners' motivation to make charitable contributions: their intrafamily succession intention, social status, and religiosity. Figure 1 summarizes the proposed relationships between these concepts.

\section{Hypotheses}

In family-controlled firms, family owners with intrafamily succession intention are motivated to engage in corporate philanthropic activities, because (1) corporate 


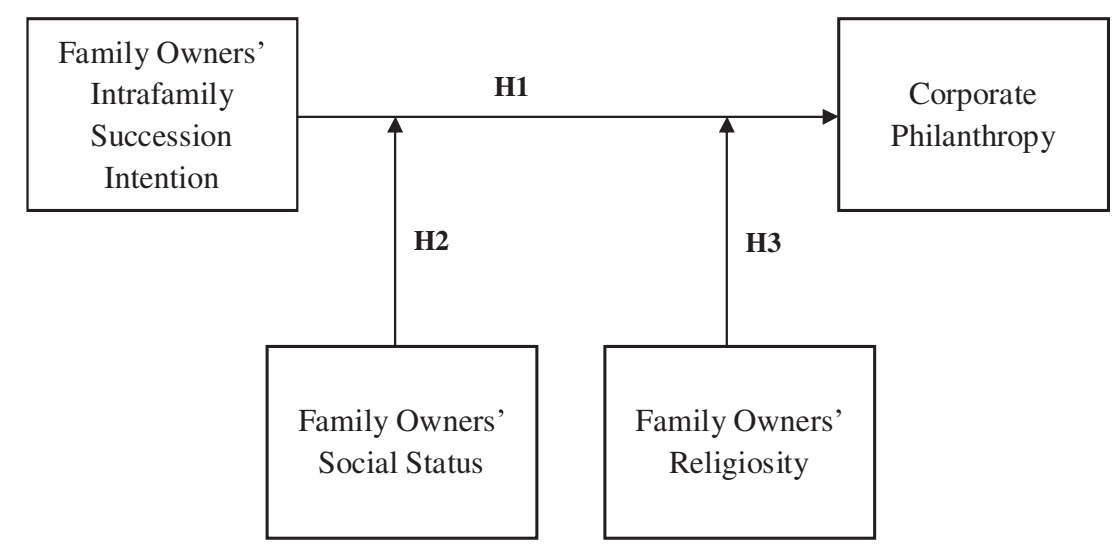

Figure 1. Drivers of charitable donations by family-controlled firms

philanthropy is a critical way to enhance family image and reputation and (2) family image and reputation, a key element of SEW, is highly valued by these family owners.

First, family-controlled firms that make substantial philanthropic contributions are likely to promote a socially responsible public image (Godfrey, 2005; Wang \& Qian, 2011). Corporate philanthropy, the top of the corporate social responsibility pyramid, plays a significant role in establishing and developing corporate reputations (Brammer \& Milington, 2005; Dutton, Dukerich, \& Harquail, 1994; Saiia, Carroll, \& Buchholtz, 2003). Given the close and often inseparable ties between family and the firm in family-controlled firms, corporate philanthropy will often serve as a crucial way to enhance family image and reputation (Zellweger et al., 2013).

Second, family owners with intrafamily succession intention place great emphasis on family image and reputation (Zellweger, Kellermanns, Chrisman, \& Chua, 2011). According to the SEW perspective, intrafamily succession intention implies that the controlling family is oriented toward a long-term vision that 'extends beyond the lifespan of the current generation' (Chrisman, Chua, Pearson, \& Barnett, 2012: 274). For this reason, as the importance of intrafamily succession increases, family owners are more likely to take steps to develop and perpetuate a positive image and reputation that is critical for long-term success (Berrone et al., 2012; Chrisman \& Patel, 2012).

Thus, as corporate philanthropy is likely to lead to a positive outcome (i.e., family image and reputation) and this outcome is highly attractive to family owners with an intrafamily succession intention, we hypothesize:

Hypothesis 1: Family owners' intrafamily succession intention will relate positively to their corporate philanthropy.

While family owners' intrafamily succession intention is expected to be associated with more charitable contributions of family-controlled firms, we draw upon the 
expectancy theory to explain how the two individual factors - social status and religiosity - can act as contingency factors qualifying the association. We consider the impact of family owners' social status first.

Social status refers to an individual's publicly acknowledged social esteem and social worth relative to other individuals in a social hierarchy (Chen, Peterson, Phillips, Podolny, \& Ridgeway, 2012). Private business owners had relatively low social status in traditional Chinese society, because, according to the Confucian scholars who did not appreciate the economic contributions of the merchants' risktaking and efficiency in facilitating the flow of goods, they selfishly harmed the common people who produced in the fields. The public image of private business owners was even worse between 1949 and 1977 when private businesses were denigrated as the 'tail of capitalism'. However, the economic reforms announced by the CPC in 1978 greatly improved the social status of private business owners (Au \& Sun, 1998). A large number of such owners are now members of the People's Congress (PG), the highest organ of state power, and the Chinese People's Political Consultative Conference (CPPCG), the top political advisory body in China ( $\mathrm{Li}$ and Liang, in press).

Drawing on expectancy theory, we propose that the social status of family owners increases their expectancy that corporate philanthropy is closely related to SEW, particularly regarding family image and status, and thus strengthens the relationship between intrafamily succession intention and corporate philanthropy. When family owners have high social status, they are well known to individuals in their communities (Ma \& Parish, 2006; Yiu et al., 2014; Zellweger et al., 2013). As a result, when family-controlled firms make charitable contributions, their philanthropic behavior is more likely to be noticed and, thus, to contribute to family image and reputation (Berrone et al., 2010; Zellweger et al., 2013). Accordingly, family owners with high social status would expect that corporate philanthropy is closely related to family SEW. Hence, high status family owners with intrafamily succession intention will have greater motivation to make charitable donations to maintain or increase their individual and family status.

By contrast, when family owners are of relatively low social status, the relationship between intrafamily succession intention and corporate philanthropy might become weaker. These family owners experience less social monitoring, and their charitable contributions are less likely to be noticed (Zellweger et al., 2013). Thus, they might have a lower corporate philanthropy-SEW expectancy. Consequently, even if they have intrafamily succession intention, they might be less motivated to make charitable contributions, as they expect that there is only a weak link between corporate philanthropy and family image and reputation. Hence, we hypothesize:

Hypothesis 2: Family owners' social status will moderate the positive relationship between family owners' intrafamily succession intention and corporate philanthropy. Specifically, the positive relationship between family owners' intrafamily succession intention and corporate 
philanthropy will be stronger for family owners with high social status than for those of low social status.

While the state continues to maintain tight control over religious activities in China, in recent years, more family owners have been willing to publicly profess their religious affiliations. For example, Mr. Pan Shiyi and Ms. Zhang Xin, who cofounded the largest prime office real estate development company in China, SOHO China, wrote on their blogs that they had converted to the Baha'i faith. Similarly, Mr. Huang Rulun, the founder of Century Golden Resources Group, publicly announced his affiliation with Buddhism. Indeed, when we calculated the percentage of family owners professing attachment to a particular religion based on the nationwide survey of privately owned enterprises that we used to test our hypotheses, we found that this percentage had increased from $16.9 \%$ to $21 \%$ in just two years, from 2008 to 2010.

Family owners with religiosity, we argue, are likely to value corporate philanthropy intrinsically. Although all branches of religion may have different behavioral codes, one trait they have in common is encouraging charity and caring for the poor (McGuire, Newton, Omer, \& Sharp, 2012). For example, Buddhist scripture encourages universal compassion, which refers to an active willingness to bear the pain of others (Norberg-Hodge, 1997). Similarly, in Christianity, charity is held to be the ultimate perfection of the human spirit. Through daily exposure to religious norms, individuals who identify with particular religious denominations are likely to follow these norms and see charity as an end in and of itself (Parboteeah, Hoegl, \& Cullen, 2007; Ramasamy, Yeung, \& Au, 2010).

This is particularly true in China, where religious affiliation is more of a personal choice than the result of a parental decision or social calling. Because very few religious believers and practitioners remained when the government began to loosen control over religion in 1978, individuals in China, especially family owners, were unlikely to have acquired their religious views from their parents (Lai, 2003). As a result, compared to their counterparts in Western countries, family owners in China who are affiliated with a particular religion are more likely to have internalized their religious teachings and to have a genuine interest in making charitable contributions.

Drawing upon expectancy theory, we propose that because family owners with religious faith value corporate philanthropy for itself rather than for the utilitarian benefits derived from it, there will be a weaker relationship between intrafamily succession intention and corporate philanthropy. Specifically, these family owners are likely to donate for intrinsic reasons and rely much less on extrinsic rewards for their motivation (McGuire et al., 2012). That is, when family owners are religious, it is less likely that extrinsic reward (i.e., SEW) will be the main driver of their corporate philanthropy, and the relationship between intrafamily succession intention and corporate philanthropy will be weaker. As a case in point, Mr. Huang Rulun, a Buddhist and number two on the Hurun list of top philanthropic donors in China, 
stated that he firmly believed that charity should be spontaneous and not conducted for personal glory or gain. Hence, based on this discussion, we hypothesize:

Hypothesis 3: Family owners' religiosity will negatively moderate the positive relationship between family owners' intrafamily succession intention and corporate philanthropy. Specifically, the positive relationship between family owners' intrafamily succession intention and corporate philanthropy will be weaker when family owners are religious than when they are not.

\section{METHOD}

\section{Empirical Setting}

Our main data source was a nationwide survey conducted in 2010 of privately owned Chinese enterprises. The survey provided a reliable database on privately owned businesses in China and has been used in studies published in leading journals (e.g., Jia, 2014; Zhou, 2013). Starting in 1991, the research team conducted a nationwide survey approximately every two years (1991, 1993, and so on until 2010). Unfortunately, the enterprises selected in the previous surveys were not tracked in the latter ones, so a longitudinal investigation of each firm's corporate social performance was not feasible. Thus, we chose the latest version of the survey, the 2010 National Survey, as the dataset for hypothesis testing. Differing from its previous versions, the 2010 National Survey added items measuring family owners' intrafamily succession intention; thus, it was appropriate for our hypothesis testing. The response rate for this survey was $95 \%$.

We classify a firm as a family-controlled one when a family owns at least $50 \%$ of the shares. Most prior studies on family-controlled firms have been on listed firms and have used 5\% as the cutoff point defining family-controlled firms. Our focus was on private enterprises; thus, we required a more stringent criterion. The $50 \%$ benchmark ensured that the family owner had the discretion to engage in behaviors enhancing family SEW.

After we removed observations with missing key explanatory variables, the final sample contained 1,923 observations. We also used other ownership percentages as cutoff points in the robustness tests.

\section{Dependent Variable}

Corporate philanthropy was assessed by the total amount of charitable donations that a firm made in 2009, scaled by the firm's sales. Such scaling was used to control for the effect of firm size; larger firms are generally able to support higher levels of corporate charity. Corporate philanthropy typically accounts for a small proportion of a firm's sales. This might lead to regression coefficients too small to be interpreted. Hence, we multiplied the scaled measure by 1,000. The amount of charitable giving was measured by a question: How much did your firm donate to charity in 2009 ? 
A firm's sales revenue was measured by a question: What was the amount of your company's annual revenue? It should be noted that the value of such a measure of corporate philanthropy can be very large when a firm that made charitable contributions generated extremely low sales revenue. However, the hypotheses testing results were basically the same when we excluded firms from our analyses whose values of corporate philanthropy were extremely high.

\section{Independent and Moderating Variables}

Intrafamily succession intention was measured by the question: Do you intend to give the next generation ownership or management control of the business? This is a dummy variable, coded 1 if the respondent intends to pass on management or ownership control to the next generation, and 0 otherwise.

We used family owners' political representation in the PC and CPPCC to assess the family owners' social status, using a dummy variable coded as 1 if a family owner was a member of the PC or CPPCC, and 0 otherwise. The PC is the highest organ of state power in China, whereas the CPPCG is the top political advisory body. Hence, membership in the PG or CPPCG reflects a family owner's social status in the community (Li \& Liang, in press). Furthermore, this measure was less subject to individual bias, as the family owners were required to simply report in the questionnaire whether they were members of the PC or CPPCC or not.

Religiosity was measured by a dummy variable, set to 1 if the family owner was affiliated with a religion, and 0 otherwise.

\section{Control Variables}

Several control variables were also included. According to upper echelons theory, family owners' demographic characteristics can influence key firm decisions. Hence, we controlled for a set of variables concerning demographic characteristics, including age, gender, and education. Owner's age was measured in years. Gender was measured by a dummy variable set to 1 for male and 0 for female. Education was measured by a six-point scale item, asking respondents to indicate their education level $(1=$ primary school or below; $2=$ junior middle school; $3=$ senior high school or vocational school; $4=$ junior college; $5=$ university; $6=$ postgraduate). Because family owners' financial positions may also have a bearing on how much they are willing to donate, we also controlled for family owners' salaries.

Further, we controlled for a set of firm characteristics. Firm size was measured as the natural log of total employees. Firm age was measured as the number of years since the firm's inception. We also controlled for firm profitability, which has been shown to be associated with corporate philanthropy (Waddock \& Graves, 1997). Firm profitability was measured as the net profit in the year 2008.

In addition, we controlled for family ownership and family management, because both may increase a controlling family's motivation to accumulate or maintain 
SEW. Family ownership was measured as the percentage of ownership held by the controlling family. Family management is a dummy variable, coded as 1 if one of the family members served as board chair or the CEO of the firm, and 0 otherwise. Finally, 18 industry dummies and 31 region dummies were included in the analyses to control for industry and regional effects.

\section{Estimation Method}

In this study, an ordinary-least-squares regression model was used to test the hypotheses. We first entered all of the control variables and then the variable of family owners' succession intention; interaction effects were added in subsequent models. Because the data we used came from a stratified sample, it was desirable to make statistical adjustments. Accordingly, we clustered standard errors by industry for each regression model.

\section{RESULTS}

Table 2 presents the descriptive statistics and a correlation matrix of the variables. The magnitude of the correlations between the independent variables is in the low-to-medium range, suggesting that multicollinearity could be a problem in the testing of the hypotheses. To address this issue, we inspected variance inflation factors (VIFs) in a parallel set of models. The VIFs were well within the limit of 10, indicating that multicollinearity did not seem to have an undue influence on the estimates.

Table 3 presents the results based on hierarchical multiple regression analysis. Model 1 is the baseline model, including only control variables. Model 2 provides the results of testing the main effect. As presented in Model 1, intrafamily succession intention has a significant and positive influence on corporate philanthropy $(\beta=$ $8.41, \mathrm{p}<0.01)$. Hypothesis 1 , which predicts that intrafamily succession intention is positively related to corporate philanthropy, is thus supported. It is worth noting that family ownership and family management do not have significant relationships with corporate philanthropy.

Model 3 in Table 3 shows the results for Hypothesis 2, which predicts that the positive influence of intrafamily succession intention on corporate philanthropy will be heightened by the family owner's social status. The coefficients for the interaction between intrafamily succession intention and family owners' social status are positive and significant $(\beta=13.29, \mathrm{p}<0.01)$. Figure 2 illustrates the moderating effect. Following the procedure proposed by Aiken and West (1991) and Jaccard and Turrisi (2003), we performed simple slope tests to examine the relationship between intrafamily succession intention and corporate philanthropy when family owners had high and low social status. The simple slope tests show that intrafamily succession intention is significantly and positively related with corporate philanthropy $(\mathrm{p}<0.01)$ when family owners have high social status (i.e., a social 
Table 2. Descriptive statistics and correlation matrix ${ }^{a}$

\begin{tabular}{|c|c|c|c|c|c|c|c|c|c|c|c|c|c|c|}
\hline Variables & Mean & S.D. & 1 & 2 & 3 & 4 & 5 & 6 & 7 & 8 & 9 & 10 & 11 & 12 \\
\hline 1. Corporate philanthropy & 98.94 & 4685.11 & & & & & & & & & & & & \\
\hline 2. Owner age & 45.86 & 8.84 & 0.02 & & & & & & & & & & & \\
\hline 3. Owner gender & 0.84 & 0.37 & 0.01 & 0.05 & & & & & & & & & & \\
\hline 4. Owner education & 3.80 & 1.11 & 0.05 & -0.15 & -0.03 & & & & & & & & & \\
\hline 5. Owner salary & 13.41 & 29.31 & 0.00 & 0.06 & 0.05 & 0.11 & & & & & & & & \\
\hline 6. Firm size & 3.75 & 1.62 & 0.00 & 0.22 & 0.09 & 0.19 & 0.22 & & & & & & & \\
\hline 7. Firm age & 10.75 & 4.76 & 0.00 & 0.24 & 0.06 & 0.03 & 0.12 & 0.27 & & & & & & \\
\hline 8. Net profit & 436.99 & 3647.72 & 0.00 & 0.07 & 0.00 & -0.02 & 0.15 & 0.19 & 0.07 & & & & & \\
\hline 9. Family ownersl & 90.98 & 16.12 & 0.01 & -0.05 & 0.03 & -0.09 & -0.01 & -0.06 & 0.05 & 0.00 & & & & \\
\hline 10. Family management & 1.00 & 0.06 & 0.00 & 0.00 & 0.01 & -0.01 & 0.01 & 0.00 & 0.05 & 0.00 & 0.02 & & & \\
\hline 11. Social status & 0.51 & 0.50 & 0.02 & 0.14 & 0.07 & 0.14 & 0.13 & 0.43 & 0.31 & 0.07 & 0.02 & 0.01 & & \\
\hline 12. Religious belief & 0.22 & 0.41 & 0.01 & 0.04 & 0.03 & -0.06 & 0.06 & 0.09 & 0.09 & 0.03 & -0.01 & -0.03 & 0.07 & \\
\hline 13. Succession intention & 0.34 & 0.47 & 0.03 & 0.21 & 0.01 & -0.11 & 0.08 & 0.07 & 0.09 & 0.02 & 0.06 & -0.01 & 0.05 & 0.08 \\
\hline
\end{tabular}

Notes: ${ }^{a}$ Net profit is measured for year $\mathrm{t}-1$; other variables, for $\mathrm{t}, \mathrm{n}=1,923$. Correlations greater than or equal to $|0.05|$ are significant at $\mathrm{p}<0.05$. Correlations greater than or equal to $|0.06|$ are significant at $\mathrm{p}<0.01$. 
Table 3. Results of hypotheses testing using hierarchical regression analysisabc

\begin{tabular}{|c|c|c|c|c|c|}
\hline & Model 1 & Model 2 & Model 3 & Model 4 & Model 5 \\
\hline Intercept & $\begin{array}{c}-52.50^{* *} \\
(22.60)\end{array}$ & $\begin{array}{c}-51.52^{* *} \\
(20.64)\end{array}$ & $\begin{array}{c}-49.62^{* *} \\
(21.16)\end{array}$ & $\begin{array}{c}-55.44^{* *} \\
(24.10)\end{array}$ & $\begin{array}{c}-53.43^{* *} \\
(25.05)\end{array}$ \\
\hline 1. Owner age & $\begin{array}{c}0.45^{+} \\
(0.23)\end{array}$ & $\begin{array}{c}0.39^{+} \\
(0.19)\end{array}$ & $\begin{array}{c}0.37^{+} \\
(0.20)\end{array}$ & $\begin{array}{c}0.42^{* *} \\
(0.19)\end{array}$ & $\begin{array}{l}0.41^{* *} \\
(0.19)\end{array}$ \\
\hline 2. Owner gender & $\begin{array}{l}4.25 \\
(3.22)\end{array}$ & $\begin{array}{c}4.43 \\
(3.03)\end{array}$ & $\begin{array}{c}4.74 \\
(3.05)\end{array}$ & $\begin{array}{c}4.07 \\
(3.05)\end{array}$ & $\begin{array}{c}4.42 \\
(3.08)\end{array}$ \\
\hline 3. Owner education & $\begin{array}{l}5.29^{* * *} \\
(1.42)\end{array}$ & $\begin{array}{l}5.59^{* * *} \\
(1.46)\end{array}$ & $\begin{array}{l}5.47^{* * * *} \\
(1.43)\end{array}$ & $\begin{array}{l}5.70^{* * * *} \\
(1.45)\end{array}$ & $\begin{array}{l}5.57^{* * *} \\
(1.40)\end{array}$ \\
\hline 4. Owner salary & $\begin{array}{c}-0.04 \\
(0.08)\end{array}$ & $\begin{array}{c}-0.05 \\
(0.08)\end{array}$ & $\begin{array}{c}-0.05 \\
(0.08)\end{array}$ & $\begin{array}{c}-0.05 \\
(0.08)\end{array}$ & $\begin{array}{c}-0.05 \\
(0.08)\end{array}$ \\
\hline 5. Firm size & $\begin{array}{c}-1.43 \\
(1.70)\end{array}$ & $\begin{array}{c}-1.42 \\
(1.73)\end{array}$ & $\begin{array}{c}-1.27 \\
(1.78)\end{array}$ & $\begin{array}{r}-1.49 \\
(1.70)\end{array}$ & $\begin{array}{c}-1.33 \\
(1.74)\end{array}$ \\
\hline 6. Firm age & $\begin{array}{c}-0.25 \\
(0.42)\end{array}$ & $\begin{array}{c}-0.27 \\
(0.42)\end{array}$ & $\begin{array}{c}-0.28 \\
(0.42)\end{array}$ & $\begin{array}{c}-0.32 \\
(0.43)\end{array}$ & $\begin{array}{r}-0.33 \\
(0.43)\end{array}$ \\
\hline 7. Net profit & $\begin{array}{c}-0.00 \\
(0.00)\end{array}$ & $\begin{array}{r}-0.00 \\
(0.00)\end{array}$ & $\begin{array}{r}-0.00 \\
(0.00)\end{array}$ & $\begin{array}{r}-0.00 \\
(0.00)\end{array}$ & $\begin{array}{c}-0.00 \\
(0.00)\end{array}$ \\
\hline 8. Family ownership & $\begin{array}{c}0.10 \\
(0.07)\end{array}$ & $\begin{array}{c}0.09 \\
(0.07)\end{array}$ & $\begin{array}{c}0.09 \\
(0.07)\end{array}$ & $\begin{array}{c}0.09 \\
(0.07)\end{array}$ & $\begin{array}{c}0.09 \\
(0.08)\end{array}$ \\
\hline 9. Family management & $\begin{array}{l}9.67^{* *} \\
(3.94)\end{array}$ & $\begin{array}{l}9.95^{* *} \\
(4.12)\end{array}$ & $\begin{array}{c}9.78^{+} \\
(4.80)\end{array}$ & $\begin{array}{c}9.35 \\
(6.37)\end{array}$ & $\begin{array}{c}9.12 \\
(7.74)\end{array}$ \\
\hline 10. Social status & $\begin{array}{c}6.47^{+} \\
(3.60)\end{array}$ & $\begin{array}{c}6.48^{+} \\
(3.61)\end{array}$ & $\begin{array}{c}2.02 \\
(2.70)\end{array}$ & $\begin{array}{c}7.31^{+} \\
(3.72)\end{array}$ & $\begin{array}{c}2.12 \\
(2.70)\end{array}$ \\
\hline 11. Religiosity & $\begin{array}{l}2.83 \\
(5.99)\end{array}$ & $\begin{array}{l}2.45 \\
(6.04)\end{array}$ & $\begin{array}{c}2.11 \\
(6.02)\end{array}$ & $\begin{array}{c}13.80 \\
(9.30)\end{array}$ & $\begin{array}{l}14.06 \\
(9.37)\end{array}$ \\
\hline 12. Succession intention & & $\begin{array}{l}6.96^{* *} \\
(3.21)\end{array}$ & $\begin{array}{c}0.46 \\
(4.05)\end{array}$ & $\begin{array}{l}13.26^{* * *} \\
(4.55)\end{array}$ & $\begin{array}{c}5.99 \\
(4.38)\end{array}$ \\
\hline $\begin{array}{l}\text { 13. Succession intention* } \\
\text { Social status }\end{array}$ & & & $\begin{array}{c}12.82^{* *} \\
(5.78)\end{array}$ & & $\begin{array}{c}15.08^{* *} \\
(6.20)\end{array}$ \\
\hline $\begin{array}{l}\text { 14. Succession intention* } \\
\text { Religiosity }\end{array}$ & & & & $\begin{array}{c}-28.24^{* *} \\
(9.87)\end{array}$ & $\begin{array}{c}-29.89^{* * *} \\
(10.17)\end{array}$ \\
\hline $\begin{array}{l}\mathrm{R}^{2} \\
\Delta \mathrm{R}^{2}\end{array}$ & 0.16 & $\begin{array}{l}0.17 \\
0.01\end{array}$ & $\begin{array}{l}0.19 \\
0.03\end{array}$ & $\begin{array}{l}0.19 \\
0.03\end{array}$ & $\begin{array}{l}0.21 \\
0.05\end{array}$ \\
\hline
\end{tabular}

Notes: ${ }^{\mathrm{a}} \mathrm{n}=1,923$ observations. Bracketed numbers are standardized errors.

${ }^{\mathrm{b}+} \mathrm{p}<0.10,{ }^{*} \mathrm{p}<0.05,{ }^{* *} \mathrm{p}<0.01$, and ${ }^{* * *} \mathrm{p}<0.001 ;$ two-tailed tests.

${ }^{\mathrm{c}}$ All three models include 18 industry dummy variables and 31 region dummy variables not reported here.

status that is one standard deviation above the mean social status). In contrast, the relationship between intrafamily succession intention and corporate philanthropy is insignificant when family owners have low social status (i.e., a social status that is one standard deviation below the mean social status). Hypothesis 2 is thus supported.

Model 4 in Table 3 presents the results of testing Hypothesis 3, which predicts that the positive effect of intrafamily succession intention on corporate philanthropy will be weaker when the family owners are affiliated with a religion. As predicted, the interaction term between intrafamily succession intention and a family owner's religiosity is negative and significant $(\beta=-28.93, \mathrm{p}<0.01)$. Figure 3 illustrates the moderating effect. The slope of those with religiosity is flatter than that of those 


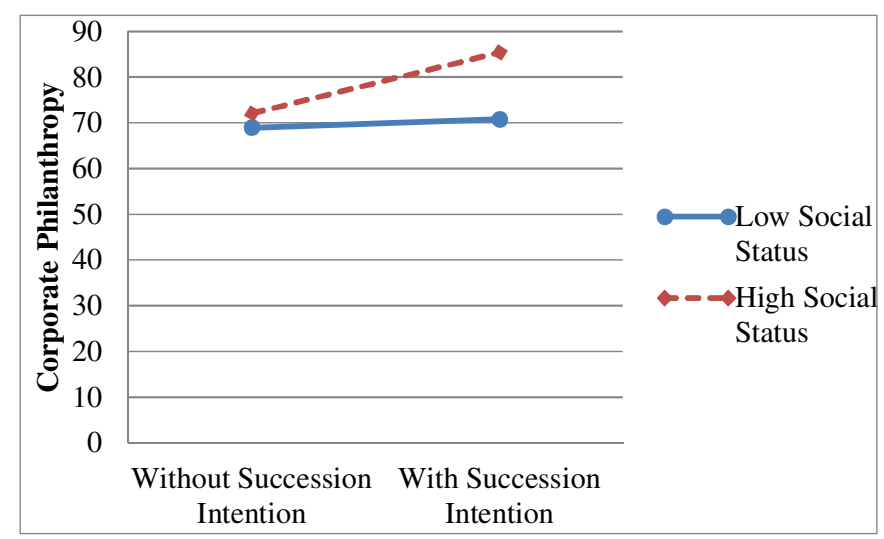

Figure 2. Interaction effect of family owners' intrafamily succession intention and family owners' social status on corporate philanthropy (Color online)

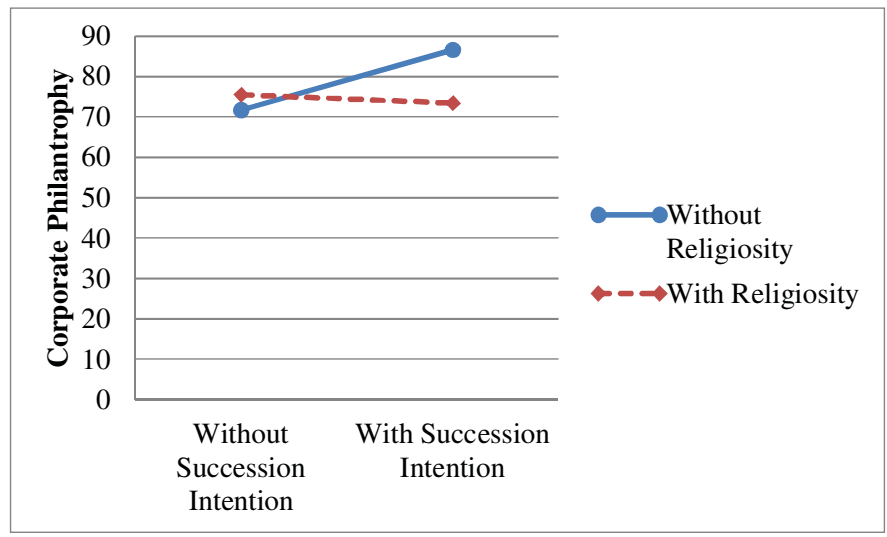

Figure 3. Interaction effect of family owners' intrafamily succession intention and family owners' religiosity on corporate philanthropy (Color online)

without religious affiliations. A simple slope test shows that intrafamily succession intention is significantly and positively associated with corporate philanthropy ( $\mathrm{p}$ $<0.01)$ when family owners are not affiliated with a religion. In contrast, the relationship between intrafamily succession intention and corporate philanthropy is not significant when the family owners are affiliated with a religion. Thus, Hypothesis 3 is supported.

Model 5 in Table 3 shows the results of simultaneously testing Hypotheses 2 and 3 by adding the two interaction terms associated with social status and religiosity. Again, the results provide strong support for the two moderating effect hypotheses.

\section{Robustness Check ${ }^{[1]}$}

We examined whether our results were robust to the alternative estimation method, using Heckman's two-stage treatment regression to test our hypotheses. Two-stage 
treatment effects models are less susceptible to the proliferation of specification errors and distortions. Specifically, the first stage of the procedure is a probit analysis with intrafamily succession intention as the dependent variable. To meet the exclusion restrictions that are necessary for identification in Heckman's model, we included a variable in the probit model that we did not include in the secondstage regression. This was a dummy variable on the next generation's willingness to succeed, coded as 1 if the next generation was willing to take over the familycontrolled firm, and 0 otherwise. The results from the treatment effects estimation were qualitatively the same as those reported in Table 3. ${ }^{[2]}$

We further verified the robustness of our results by using an alternative measure of social status. In the questionnaire, the family owners were asked to rate their relative social standing in the community by a ten-point scale $(1=$ highest; $10=$ lowest). For the analyses, we transformed this rating by subtracting the original rating from 11. Such a subjective social status measure is common in sociological research (Haug, 1977; Ma \& Parish, 2006). For example, in a study of private entrepreneurs in China, Ma and Parish (2006) used the subjective social status to measure the social standings of the family owners. The results of the regression analyses employing this alternative measure of social status were consistent with those reported in Table 3.

Finally, we also used $20 \%$ and $30 \%$ of firm ownership as the cutoff points to differentiate family-controlled firms from nonfamily-controlled firms. After deleting firms from our sample in which the family owned less than $20 \%$ or $30 \%$ of the equity, we reran the analyses. The empirical results from these analyses again were qualitatively the same as those reported in Table 3.

\section{DISGUSSION}

Recent interest in the role of SEW has contributed to understanding the behaviors of family-controlled firms (e.g., Leitterstorf \& Rau, 2014). We extend this understanding by investigating the variations among family-controlled firms, specifically those related to corporate philanthropy. We found that intrafamily succession intention was significantly related to corporate philanthropy. This finding is consistent with prior studies indicating that this intention is a potential source of heterogeneity among family-controlled firms. Moreover, our empirical results show that intrafamily succession intention plays a much more important role in driving corporate philanthropy when family owners are of relatively high social status and when they are without a religious affiliation. These findings provide support for the argument in prior studies that the personal features of family owners play an important role in explaining their perceptions of SEW (Naldi et al., 2013) and that ability alone is insufficient to produce family firm particularistic behavior; willingness or motivation must also be present (De Massis, Kotlar, Chua, \& Chrisman, 2014). 


\section{Contributions and Implications}

This study makes several important theoretical contributions. First, it contributes to the research on family-controlled firms by integrating insights from expectancy theory. As indicated above, a common assumption in empirical studies that have applied the SEW perspective is that family owners are homogeneous in their emphasis on SEW. Although recent studies on SEW have indicated that family owners' personal features might play a role in influencing their perceptions of SEW and their firm's behaviors (Kellermanns et al., 2012), this study is the first to provide specific theoretical and empirical insight into when and how these personal features may shape the behavior of family-controlled firms. Drawing on expectancy theory, we posit that whether a family owner is willing to make charitable contributions is highly dependent on the possibility that these contributions will lead to a positive outcome and attractiveness of this outcome. Accordingly, family owners' intrafamily succession intention, social status, and religiosity might interact with each other to determine the family owners' motivation for engaging in corporate philanthropic activities. There have been calls for an examination of the antecedents of heterogeneity among family-controlled firms (Chrisman \& Patel, 2012; Chua et al., 2012), and this study is a response, providing a systematic understanding of the motivational factors underlying the behavior of family-controlled firms.

Future research on SEW could benefit by drawing on insight from other psychological theories as well. Zellweger and Dehlen (2012) integrated the affect infusion model from cognitive psychology with the SEW perspective and developed a conceptual model explaining how affect might influence family owners' SEW perception. Our study represents another attempt to use the lens of psychology to explain variations in behavior between family-controlled firms. To the extent that a family owner's decision making related to SEW considerations is a cognitive process, other psychological theories such as goal-setting theory and social cognitive theory might also add value to a better understanding of family SEW.

Second, our study contributes to the research on SEW by suggesting that family involvement in ownership and management may not be a sufficient condition for the family to accumulate and maintain SEW. Indeed, our empirical results in Table 3 show that intrafamily succession intention is more strongly associated with corporate philanthropy than is family involvement in ownership and management. We argue that this occurs because family involvement only provides family members with the ability to maintain or increase SEW, whereas their intrafamily succession intention determines their willingness to do so. Without intrafamily succession intention, family members may not use their influence to pursue family-centered noneconomic goals. To advance this perspective on SEW, future studies should take both family involvement and intrafamily succession intention into consideration.

Third, our findings also contribute to a better understanding of the behavior of family-controlled firms in China. The institutional environment in China has experienced significant changes during the past three decades. Family owners may 
respond to these changes by adjusting their goals, which, in turn, might have a great impact on their firm's behavior (Peng, Sun, Pinkham, \& Chen, 2009). Since 1978, the Chinese government has gradually abandoned its discrimination against familycontrolled firms and softened its official policies toward religion. As a result, family owners are now allowed to seek higher social status, for example, through winning a seat in the PC or the CPPCC. Increasing numbers are also publicly declaring their religious affiliation. In this study, we have examined whether family owners' social status and religious affiliation, both of which have been greatly shaped by the recent institutional developments, influence their corporate philanthropy. Our empirical finding that social status and religious affiliation interact with intrafamily succession intention to influence family-controlled firms' charitable contributions greatly enhances our understanding of the evolving nature of family business in China. While a number of recent studies have examined the social status of family owners (Jia, 2014), the role of religion in the growth of family-controlled firms and social development of China may also be a fruitful topic for future research. For example, studies could investigate how the religiosity of business owners and corporate executives might have an impact on corporate social entrepreneurship.

In addition, future research might benefit from investigating the effect of institutional changes on family-controlled firms' charitable donations. For example, loosening controls on family-controlled firms would lead to more family business owners being willing to make charitable contributions. Thus, investigators could attempt to extend this research by examining how formal institutional changes influence the corporate philanthropy of family-controlled firms.

Furthermore, in addition to examining the effect of institutional differences across time, we would like to see more research on the influence of regional institutional differences. For example, Du, Jian, Du, Feng, and Zeng (2014) noted great variations in local religiosity across provinces in China. Local religiosity refers to the intensity of religious beliefs within the local community. In regions where religion plays a prominent role, religious beliefs can become part of the social norm shaping individual behaviors. Hence, more work can be done to examine how local religiosity might interact with family owners' goals and values in influencing corporate philanthropy.

\section{Limitations}

A few limitations of this study should be acknowledged. First, our sample consisted of privately owned firms in China, a major emerging economy. Thus, the nature of the sample may limit the generalizability of the findings to developed economies. China differs from developed economies substantially in terms of institutional arrangements, which might play a role in shaping corporate philanthropy. Hence, future research in this area would benefit from an investigation into whether intrafamily succession intention influences corporate philanthropy in other institutional settings. 
Second, although we have argued that family owners with intrafamily succession intention engage in corporate philanthropy to accumulate or preserve their SEW, data limitations prevented us from directly measuring the dimensions of SEW that play a more critical role. Berrone et al. (2012) pointed out that SEW has multiple dimensions, each of which might play a different role in influencing family-controlled firms' behavior. Researchers should investigate the underlying mechanisms and examine which SEW dimensions drive corporate philanthropy.

Third, although all religions encourage charity and caring for society, there are slight differences in group norms across religions. In our sample, among those who had a religious affiliation, $80.5 \%$ of the family owners were affiliated with Buddhism. The relatively small number of family owners affiliated with other religions prevented us from detecting significant effects because of low statistical power. In-depth interviews with family owners affiliated with different religions might be a more fruitful way to examine the role of religious norms in driving corporate philanthropy.

Finally, because our data were collected by a stratified sampling method, ideally, we would have made adjustments to estimation models by clustering standard errors by both regions and industry sectors. However, because the data on whether a firm was from a rural or urban area were unavailable, we were unable to cluster standard errors by region. Therefore, the empirical results need to be interpreted with caution.

\section{Practical Implications}

The results of our study also have a number of practical implications. Government agencies and nongovernmental organizations (NGOs) around the world have been actively promoting corporate philanthropy among different types of companies. However, they have focused mainly on providing economic incentives or generating institutional pressure. The findings of this study suggest that corporate philanthropy is greatly shaped by the goals, social standing, and personal values of family owners. Hence, government agencies and NGOs might consider complementing their current practices with a more nuanced approach that links corporate philanthropy with family owners' SEW. For example, they might encourage the succession of family businesses to the next generation and seek ways to raise the social status of family owners.

\section{GONGLUSION}

This study uses expectancy theory and the SEW perspective to investigate the sources of variation in the behaviors of family-controlled firms. The results show that family owners' intrafamily succession intention is the key factor that shapes family-controlled firms' corporate philanthropy. Their social status and religiosity moderate that relationship. This study contributes to a better understanding of 
the differences among family-controlled firms and to the evolving nature of family businesses, particularly in China.

\section{SUPPLEMENTARY MATERIAL}

To view supplementary material for this article, please visit http://dx.doi.org/ $10.1017 /$ mor. 2015.10

\section{NOTES}

We are grateful to Jess Chua, Anne S. Tsui, and two anonymous reviewers for highly constructive and detailed feedback on a previous version of our article. We also appreciate the support by the National Natural Science Foundation of China (Grant Nos. 71202095, 71232009, 71372155, 71332004, and 71102044), the Guangdong Natural Science Foundation (Grant No. S2012040007820), the Guangdong Planning Office of Philosophy and Social Science Program (GD14XGL13), and the Fundamental Research Funds for the Gentral Universities (Grant No. 13wkpy13).

[1] The robustness check results are available upon request.

[2] Our two-stage Heckman treatment regression might not fully address the potential endogeneity concern. For example, family owners with collectivistic orientations are more likely to have intrafamily succession intention. These family owners also may have a higher tendency to engage in corporate philanthropic activities.

\section{REFERENGES}

Au, K., Craig, J., \& Ramachandran, K. (Eds.) 2011. Family enterprising in Asia: Exploring transgenerational entrepreneurship in family firms. Cheltenham, UK: Edward Elgar.

Au, K., \& Sun, S. L. 1998. Hope Group: The future of private enterprises in China. Asian Case Research Journal, 2(2): 133-148.

Aiken, L. S., \& West, S. G. 1991. Multiple regression: Testing and interpreting interactions. Thousand Oaks, CA: Sage.

Berrone, P., Cruz, C., \& Gomez-Mejia, L. R. 2012. Socioemotional wealth in family firms theoretical dimensions, assessment approaches, and agenda for future research. Family Business Revieze, 25(3): 258-279.

Berrone, P., Cruz, C., Gomez-Mejia, L. R., \& Larraza-Kintana, M. 2010. Socioemotional wealth and corporate responses to institutional pressures: Do family-controlled firms pollute less? Administrative Science Quarterly, 55(1): 82-113.

Brammer, S., \& Millington, A. 2005. Corporate reputation and philanthropy: An empirical analysis. Journal of Business Ethics, 61(1): 29-44.

Cennamo, C., Berrone, P., Cruz, C., \& Gomez-Mejia, L. R. 2012. Socioemotional wealth and proactive stakeholder engagement: Why family-controlled firms care more about their stakeholders. Entrepreneurship Theory and Practice, 36(6): 1153 1173 .

Chen, M. J., \& Miller, D. 1994. Competitive attack, retaliation, and performance: An expectancyvalence framework. Strategic Management Journal, 15(2): 85-102.

Chen, Y. R., Peterson, R. S., Phillips, D. J., Podolny, J. M., \& Ridgeway, C. L. 2012. Introduction to the special issue: Bringing status to the table attaining, maintaining, and experiencing status in organizations and markets. Organization Science, 23(2): 299-307.

Chiang, C. F., \& Jang, S. 2008. An expectancy theory model for hotel employee motivation. International Journal of Hospitality Management, 27(2): 313-322.

Chrisman, J. J., Chua,J. H., Pearson, A. W., \& Barnett, T. 2012. Family involvement, family influence, and family-centered non-economic goals in small firms. Entrepreneurship Theory and Practice, 36(2): 267-293. 
Chrisman, J. J., \& Patel, P. C. 2012. Variations in R\&D investments of family and nonfamily firms: Behavioral agency and myopic loss aversion perspectives. Academy of Management Journal, 55(4): 976-997.

Chua, J. H., Chrisman, J.J., \& Sharma, P. 1999. Defining the family business by behavior. Entrepreneurship Theory and Practice, 23(4): 19-39.

Chua, J. H., Chrisman, J.J., Steier, L. P., \& Rau, S. B. 2012. Sources of heterogeneity in family firms: An introduction. Entrepreneurship Theory and Practice, 36(6): 11031113.

Gui, Z., Liang, X., \& Lu, X. 2015. Prize or price? Corporate social responsibility commitment and sales performance in the Chinese private sector. Management and Organization Revieze, 11(1): 25-44.

De Massis, A., Kotlar, J., Chua, J. H., \& Chrisman, J. J. 2014. Ability and willingness as sufficiency conditions for family-oriented particularistic behavior: Implications for theory and empirical studies.Journal of Small Business Management, 52(2), 344-364.

Du, X., Jian, W., Du, Y., Feng, W., \& Zeng, Q. 2014. Religion, the nature of ultimate owner, and corporate philanthropic giving: Evidence from China.Journal of Business Ethics, 123(2): 235-256.

Dutton, J. E., Dukerich, J. M., \& Harquail, C. V. 1994. Organizational images and member identification. Administrative Science Quarterly, 39(2): 239-263.

Fudge, R. S., \& Schlacter, J. L. 1999. Motivating employees to act ethically: An expectancy theory approach. Journal of Business Ethics, 18(3): 295-304.

Godfrey, P. C. 2005. The relationship between corporate philanthropy and shareholder wealth: A risk management perspective. Academy of Management Revieze, 30(4): 777-798.

Gomez-Mejia, L. R., Cruz, C., Berrone, P., \& De Castro, J. 2011. The bind that ties: Socioemotional wealth preservation in family firms. Academy of Management Annals, 5(1): 653707.

Gómez-Mejía, L. R., Haynes, K. T., Núñez-Nickel, M., Jacobson, K. J., \& Moyano-Fuentes, J. 2007. Socioemotional wealth and business risks in family-controlled firms: Evidence from Spanish olive oil mills. Administrative Science Quarterly, 52(1): 106-137.

Gomez-Mejia, L. R., Larraza-Kintana, M., \& Makri, M. 2003. The determinants of executive compensation in family-controlled public corporations. Academy of Management Journal, 46(2): 226-237.

Gomez-Mejia, L. R., Makri, M., \& Larraza-Kintana, M. L. 2010. Diversification decisions in familycontrolled Firms. Journal of Management Studies, 47(2): 223-252.

Grant, A. M., \& Berg, J. M. 2011. Prosocial motivation at work: When, why, and how making a difference makes a difference. In K. Cameron \& G. Spreitzer (Eds.), Oxford handbook of positive organizational scholarship: 28-44. New York: Oxford University Press.

Grant, A. M., \& Mayer, D. M. 2009. Good soldiers and good actors: Prosocial and impression management motives as interactive predictors of affiliative citizenship behaviors. Journal of Applied Psychology, 94(4): 900-912.

Haug, M. R. 1977. Measurement in social stratification. Annual Revieze of Sociology, 3(1): 5177.

Jaccard, J., \& Turrisi, R. (Eds.) 2003. Interaction effects in multiple regression. Thousand Oaks, CA: Sage.

Jia, N. 2014. Are collective political actions and private political actions substitutes or complements? Empirical evidence from China's private sector. Strategic Management Journal, 35(2): $292-315$.

Kellermanns, F. W., Eddleston, K. A., \& Zellweger, T. M. 2012. Extending the socioemotional wealth perspective: A look at the dark side. Entrepreneurship Theory and Practice, 36(6): 11751182.

La Porta, R., Lopez-de-Silanes, F., \& Shleifer, A. 1999. Corporate ownership around the world. The Journal of Finance, 54(2): 471-517.

Lai, H. H. 2003. The religious revival in China. The Copenhagen Journal of Asian Studies, 18 : 40-64.

Latham, G. P., \& Pinder, C. C. 2005. Work motivation theory and research at the dawn of the twenty-first century. Annual Revieze of Psychology, 56: 485-516.

Leitterstorf, M. P., \& Rau, S. B. 2014. Socioemotional wealth and IPO underpricing of family firms. Strategic Management Journal, 35(5): 751-760. 
Li, X., \& Liang, X. 2014. In press. A Confucian social model of political appointments among Chinese private entrepreneurs. Academy of Management Journal, doi: 10.5465/amj.2012.1067.

Lu, Y., Au, K., Peng, M. W., \& Xu, E. 2013. Strategic management in private and family business. Asia Pacific Journal of Management, 30(3): 633-639.

Ma, D., \& Parish, W. L. 2006. Tocquevillian moments: Charitable contributions by Chinese private entrepreneurs. Social Forces, 85(2): 943-964.

McGuire, S. T., Newton, T. C. Omer, and Sharp, N. Y. 2012. The impact of religion on financial reporting irregularities. The Accounting Revieze, 87 (2): 645-673.

Mencius. [1895] 1970. The book of Mencius. Trans. James Legge. Reprint. New York: Dover Publications.

Naldi, L., Cennamo, G., Corbetta, G., \& Gomez-Mejia, L. 2013. Preserving socioemotional wealth in family firms: Asset or liability? The moderating role of business context. Entrepreneurship Theory and Practice, 37(6): 1341-1360.

Norberg-Hodge, H. 1997. Buddhist engagement in the global economy. Available from URL: http://ccbs.ntu.edu.tw/FULLTEXT/JR-ADM/helena.htm.

Parboteeah, K. P., Hoegl, M., \& Cullen, J. B. 2007. Ethics and religion: An empirical test of a multidimensional model. Journal of Business Ethics, 80(2): 387-398.

Patel, P. C., \& Chrisman, J. J. 2014. Risk abatement as a strategy for R\&D investments in family firms. Strategic Management Journal, 35(4): 617-627.

Peng, M. W., Sun, S. L., Pinkham, B., \& Chen, H. 2009. The institution-based view as a third leg for a strategy tripod. Academy of Management Perspectives, 23(3): 63-81.

Ramasamy, B., Yeung, M. C., \& Au, A. K. 2010. Consumer support for corporate social responsibility (CSR): The role of religion and values. Journal of Business Ethics, 91: 61-72.

Saiia, D. H., Carroll, A. B., \& Buchholtz, A. K. 2003. Philanthropy as strategy when corporate charity 'begins at home'. Business \& Society, 42(2): 169-201.

Tsiros, M., Mittal, V., \& Ross, Jr., W. T. 2004. The role of attributions in customer satisfaction: a reexamination. Journal of Consumer Research, 31(2): 476-483.

Vroom, V. H. (1964). Work and motivation. New York: John Wiley \& Sons.

Waddock, S. A., \& Graves, S. B. 1997. The corporate social performance-finance performance link. Strategic Management Journal, 18 (4): 303-319.

Wang, H., \& Qian, C. 2011. Corporate philanthropy and financial performance of Chinese firms: The roles of social expectations and political access. Academy of Management Journal, 54 (6): 1159-1181.

Yiu, D. W., Wan, W. P., Ng, F. W., Chen, X., \& Su, J. (2014), Sentimental drivers of social entrepreneurship: A study of China's Guangcai (Glorious) Program. Management and Organization Revieze, 10(1): 55-80.

Zellweger, T. M., \& Dehlen, T. 2012. Value is in the eye of the owner: Affect infusion and socioemotional wealth among family firm owners. Family Business Revieze, 25(3): 280 297.

Zellweger, T. M., Kellermanns, F. W., Chrisman, J. J., \& Chua, J. H. 2011. Family control and family firm valuation by family CEOs: The importance of intentions for transgenerational control. Organization Science, 23(3): 1-18.

Zellweger, T. M., Nason, R. S., Nordqvist, M., \& Brush, G. G. 2013. Why do family firms strive for nonfinancial goals? An organizational identity perspective. Entrepreneurship Theory and Practice, 37(2): 229-248.

Zhou, W. 2013. Political connections and entrepreneurial investment: Evidence from China's transition economy. Journal of Business Venturing, 28(2): 299-315. 
Weiwen Li (allenliweiwen@gmail.com) is Assistant Professor, Sun Yat-sen Business School, Sun Yat-sen University. His research interests include strategic leadership, family business, and corporate governance. He has published papers in the Journal of International Business Studies and Asia Pacific Journal of Management. Kevin Yuk-fai Au (kevinau@cuhk.edu.hk) is Associate Professor of Management, Chinese University of Hong Kong. He cofounded the CUHK Center for Entrepreneurship and currently serves as director. Recently, he also became the director of the CUHK Centre for Family Business. His research interests are international management, entrepreneurship, family business, and social networking. Apart from serving the academic community on the editorial boards of several journals, he has provided consulting and training for the government and for business corporations. He also serves as a director to FFI, STEP, etc.

Ai He (heai82@gmail.com) is Lecturer, School of Economics and Commerce, South China University of Technology. Her research interests include corporate diversification and corporate governance. She has published papers in Asia Pacific Journal of Management.

Lihong Song (lhsong@stu.edu.cn) is Assistant Professor of Strategic Management, School of Business, Shantou University. Her research interests include family business research, entrepreneurship, and corporate social responsibility. Her work has been published in international conferences and in several Chinese journals.

Manuscript received: March 1, 2013

Final version accepted: December 11, 2014

Accepted by: Jess Chua 